\title{
Pharmacognostic Evaluation of Melilotus officinalis Linn.
}

\author{
N. A. Sheikh ${ }^{1,2^{*}}$, T. R. Desai ${ }^{2}$, R. D. Patel $^{3}$ \\ 'Department of Pharmacology, Smt. C. V. Gajera Pharmacy Mahila College, Chakkargadh Road, Amreli 365601 (Gujarat), INDIA. \\ 2Department of Pharmacology, School of Pharmacy, R K University, Bhavnagar Highway, Kasturbadham, Rajkot 360020 (Gujarat), INDIA. \\ 3Department of Pharmacognosy, Smt. C. V. Gajera Pharmacy Mahila College, Chakkargadh Road, Amreli 365601 (Gujarat), INDIA.
}

\begin{abstract}
Background: Melilotus officinalis Linn. (Fabaceae) historically has been used for a variety of medicinal purposes. Despite the popular medicinal utilization, still no conclusive study has been reported so far regarding the pharmacognostical standardization. Aim: Thus, the present study was focused to scientifically establish a standard monograph of $M$. officinalis on the basis of pharmacognostical parameters. Material and methods: The detailed macroscopic and qualitative as well as quantitative microscopic characters of $M$. officinalis were analyzed. Results: The morphological characters of $M$. officinalis were established. The transverse section of leaf shows lamina with single layered epidermis, anomocytic stomata, mesophyll, midrib with single layered epidermis and vascular strands were present in lamina. Stem contains single layered epidermis, cortex with several layers, phloem, xylem and starch grains. Root shows the presence of cork, phloem, xylem and starch grains. The powder characteristics of M. officinalis revels the presence of Epidermis, stomata, cork, parenchyma, mesophyll, fibers, spiral and pitted xylem vessels. The quantitative microscopy of leaf of $M$. officinalis reveals Stomatal number Upper surface
\end{abstract}

$(28.75 \pm 2.5)$, Lower surface $(38.37 \pm 2.5)$; Stomatal index Upper surface $(13.10 \pm 1.50)$ Lower surface $(12.58 \pm 1.10)$; Vein islet number $(96.25 \pm$ 4.79), Vein termination number $(27.50 \pm 2.87)$ and Palisade ratio $6.5 \pm 0.58$. Conclusion: The obtained qualitative and quantitative standards would serve as a useful guide for correct identification, purity, standardization and preparation of monograph of $M$. officinalis.

Key words: Melilotus officinalis Linn, Fabaceae, Yellow Sweet clover, Melilot, Aspurk.

Correspondence:

N. A. Sheikh, Assistant Professor, Department of Pharmacology, Smt. C. V. Gajera Pharmacy Mahila College, Chakkargadh Road, Amreli 365601 (Gujarat), INDIA.

Phone no: +919974756353; Fax no: +912792232327

Email:wsheikh2@gmail.com

DOI : 10.5530/pj.2016.3.11

\section{INTRODUCTION}

Melilotus officinalis Linn. belonging to the family Leguminosae (Fabaceae), commonly known as yellow sweet clover in English and aspurk in Hindi. M. officinalis is tall robust biennial herb, $1 \mathrm{~m}$ or more in height. Recorded from Nubra and Ladakh at altitudes of 3,000 to 4,000 $\mathrm{m}$. Leaves trifoliolate: leaflets obovate, oblong or oblanceolate; flowers in lax racemes, yellowish; pods ovoid, transversely rugose, compressed brown when ripe; seeds oval, 2-3 $\mathrm{mm}$ in diameter, yellowish green, smooth. ${ }^{1}$ M. officinalis is distributed in Pakistan, Kashmir, Tibet, Russia, China, Turkey, Middle and Southern Europe, introduced in America and Tropical Africa. ${ }^{2}$ M. officinalis is reported to have antioxidants, ${ }^{3}$ In-vitro iron chelation, ${ }^{4}$ antibacterial and antitumor ${ }^{5}$ and antiinflammatory activity. ${ }^{6}$ The plant is aromatic, emollient, carminative; it relieves flatulence, externally applied as poultice for pains and aches. The small fruits are used as demulcent, maturant, tonic, aphrodisiac; useful in leucoderma. ${ }^{7}$ As an astringent M. officinalis is useful in swelling and bowel complaints. ${ }^{8}$ M. officinalis contains flavonoids and various phenolic compounds, melilotin, volatile oil, mucilage, tannin, fatty acid, triterpenes, coumarin, bishydroxycoumarin, choline and glycosides. ${ }^{9}$ As far as chemistry and pharmacology of $M$. officinalis is concerned, large number of scientific data is available but a pharmacognostical standardization study is still lacking. Hence, the present study was focused to investigate pharmacognostical properties of $M$. officinalis.

\section{MATERIAL AND METHODS}

\section{Plant collection and authentication}

M. officinalis was collected in the flowering stage from the fields of Choaglamsar, Leh, Jammu and Kashmir, India during August 2013. It was authenticated by Mr. Akhtar H. Malik, Curator, Centre for Biodiversity and Taxonomy, Department of Botany, University of Kashmir, Jammu and Kashmir, India (1915-KASH).

\section{Chemicals and instruments}

All reagents and chemicals used for pharmacognostic screening were analytical grade. Compound microscope was used for the study. The photography was done by using microscope camera using Toupview software. Camera lucida was used for determination of quantitative microscopical characters.

\section{Morphology and microscopy}

The morphological characters such as shape, size, colour, odour, taste, surface and fractures were determined. Microscopic features of M. officinalis were evaluated by preparing thin hand section. The sections were cleared with alcohol and stained. Histochemical reactions were applied with various chemicals and photo microscopy was performed with camera. The leaf constants were measured using camera lucida. ${ }^{10}$

\section{Powder microscopy}

The powder photo microscopy of shade dried M. officinalis was carried out for identification of the powder characteristics by using camera. ${ }^{11-12}$

\section{RESULTS}

\section{Morphological characteristics}

Morphological studies shows (Figure 1) that leaf was simple, long petiolate, green in colour, ovate, oblanceolate and oblong in shape, $30 \mathrm{~mm}$ long, $20 \mathrm{~mm}$ wide, slightly aromatic odour with characteristic and slightly bitter taste. Leaf had serrulate margin, obtuse apex, symmetrical base, reticulate pinnate venation, thin texture and smooth surface. The stem was green, cylindrical, upto $1 \mathrm{~m}$ long and $4 \mathrm{~mm}$ diameter, odourless and tasteless. The surface was longitudinal, yellowish lining and pubescent with short and splintery fracture. The root was light brown, cylindrical and tapering in shape, about $8 \mathrm{~cm}$ long and $0.5-1 \mathrm{~cm}$ in diameters, the root was odourless and tasteless. Longitudinal ridges and 


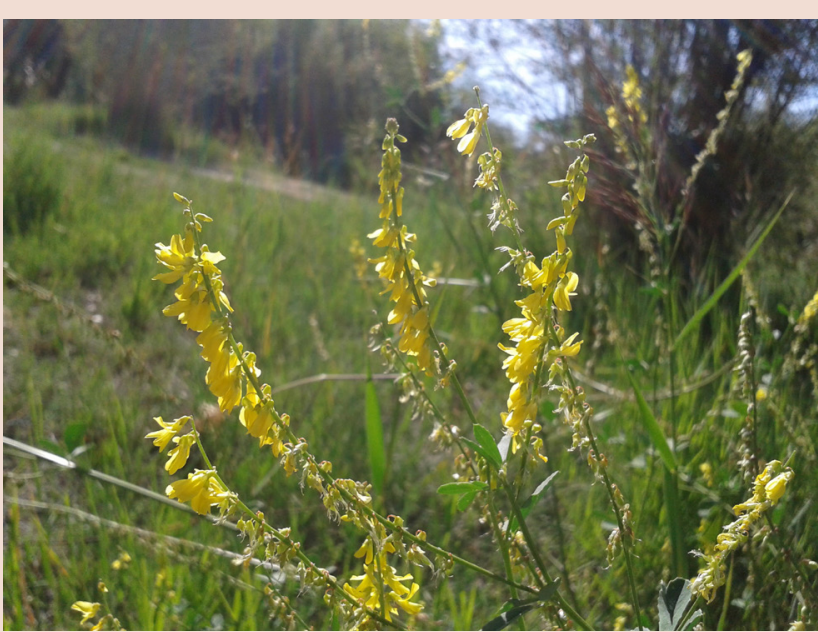

Figure 1: Plant of Melilotus officinalis.

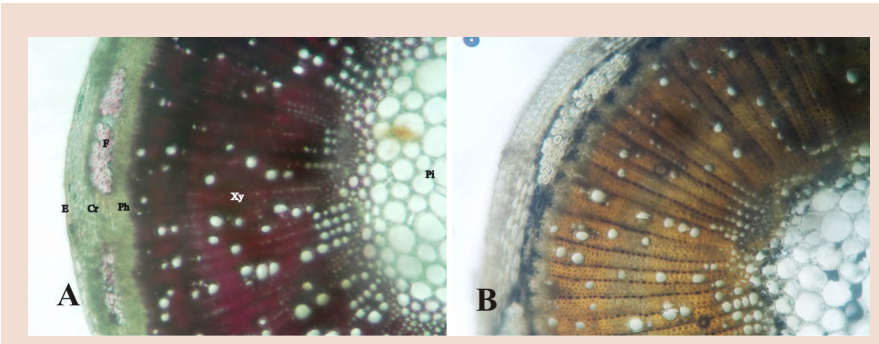

Figure 3: Photomicroscopy of transverse section of stem of $M$. officinalis. (A) Stem (10X); (B) Starch grain. (E: Epidermis, Cr: Cortical parenchyma, F: fibers, Xy: Xylem, Ph: Phloem, Pi: Pith).

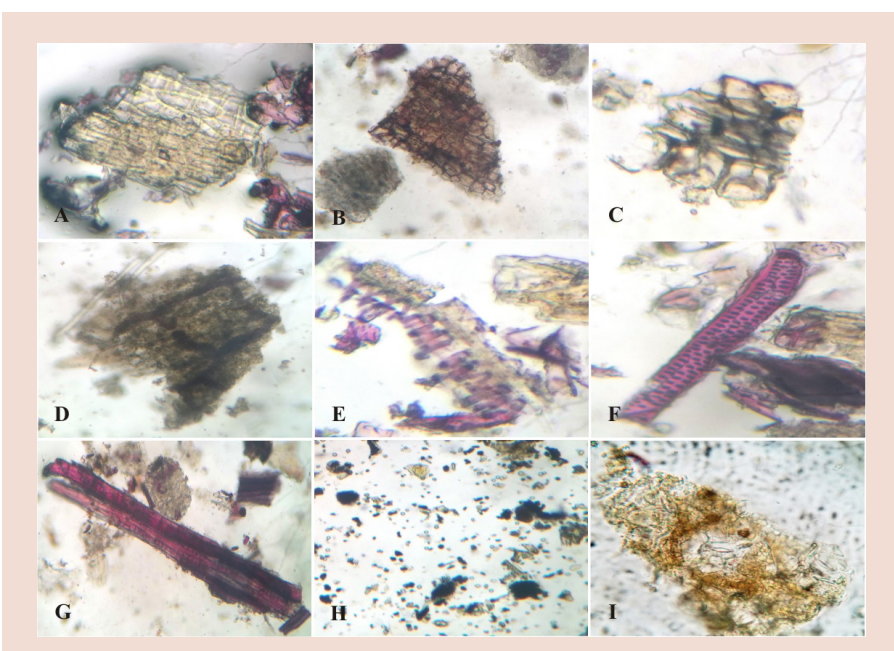

Figure 5: Photomicroscopy of powder of $M$. officinalis.

(A) Epidermis; (B) Cork; (C) Parenchyma;(D) Mesophyll; (E) Xylem vessels spiral; (F) Xylem vessels pitted; (G) Fibers; (H) Starch; (I) Stomata.

rootlets with fibrous fracture were present on surface of root. The flowers bloom in spring and summer. Present in elongated, lax, racemes, much longer than the leaves. They were medium in size and yellow in color, rarely whitish. Calyx was 2.5 time shorter than the corolla, wings and keel subequilong. The fruits were pod type, ovoid, transversely vugose,

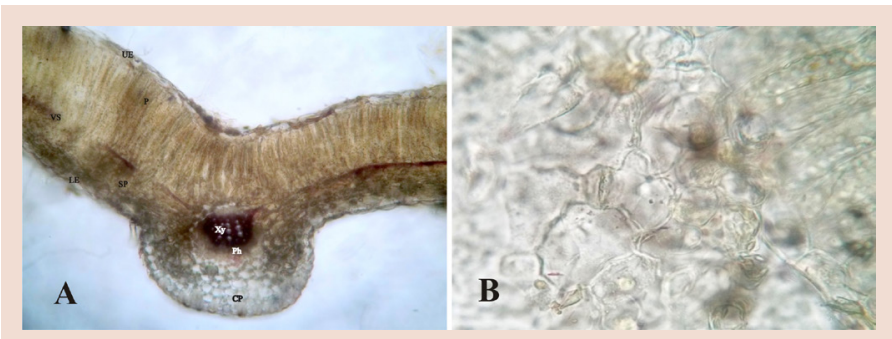

Figure 2: Photomicroscopy of transverse section of leaf of $M$. officinalis. (A) Lamina (10X); (B) Surface preparation shows anomocytic stomata. (UE: upper epidermis, LE: lower epidermis, P: Palisade cells, VS: Vascular strands, $\mathrm{Sp}$ : Spongy parenchyma, Cp: Cortical parenchyma, Xy: Xylem, Ph: Phloem).

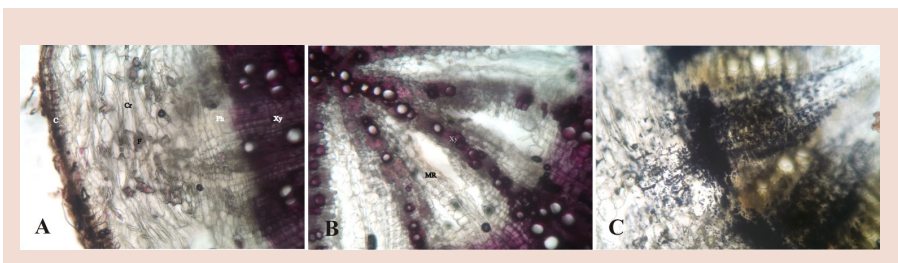

Figure 4: Photomicroscopy of transverse section of root of $M$. officinalis. (A) Root (100X); (B); Root (10X) (C); Starch grain. (C: Cork, Cr: Cortical parenchyma, F: fibers, Mr: Medullary ray Ph: Phloem, Xy: Xylem).

compressed and become brownish when ripe. The seeds were oval, 2.0-3.0 $\mathrm{mm}$ in diameter, yellowish green and had smooth surface.

\section{Qualitative microscopical characteristics Transverse section of leaf}

The transverse section of leaf was shows that upper and lower epidermis of lamina consists of single layered, rectangular parenchymatous cells, with anomocytic stomata (Figure 2A-B), lower epidermis contents more stomata. Mesophyll shows palisade double layered, vertically elongated compact cells, which continues over the midrib with several layered of thin spongy parenchyma cells, loosely arranged with intracellular spaces. Midrib was consists of upper and lower epidermis same as that of lamina, collenchyma present above lower epidermis, vascular bundles were bicolleteral type and were present in centre of midrib, rest of midrib was filled with normal parenchymatous cells. Vascular strands were present in lamina portion.

\section{Transverse section of stem}

Transverse section of stem shows that epidermis consists of single layered, rectangular tangentially elongated parenchymatous cells. Cortex consists of several layers of thin walled parenchyma cells. Patches of lignified pericyclic fibers were present throughout the cortex. Vascular bundle shows closed collateral type phloem which contains sievetubes and companion cells. Xylem were well developed, consists of xylem parenchyma, vessels and fibers. Medullary rays were also present. Pith shows large, thin walled, parenchyma cells. Starch grains were present abundantly in cortex, medullary rays and pith portion (Figure 3A-B).

\section{Transverse section of root}

The transverse section of root revealed that cork consists of several layers of thin walled, polygonal cells with brown content. Cortex shows several layers of thin walled, irregular shaped parenchymatous cells, group of pericyclic fibers were present throughout the cortex. The phloem shows 
phloem parenchyma, sievetubes and companion cells. Xylem consists of xylem parenchyma, vessels, fibers and multiseriate medullary rays. Starch grains were scattered in cortex and xylem portion (Figure 4A-C).

\section{Powder characteristics}

The shade dried powder of $M$. officinalis has greenish brown colour, characteristic odour and sweet taste. Epidermis revealed thin walled, irregular parenchymatous cells with irregular shape. Cork consists of Polygonal isodiametric cells with brown content. Parenchyma shows thin walled polyhedral cells with intercellular space. Mesophyll consists of spongyparenchyma with vascular strands. Fragments of lignified spiral and pitted xylem vessels were detected. Fibres were lignified, long, thick walled and cylindrical in shape. Starch was simple and rounded shaped. It contains anomocytic type of stomata (Figure 5A-I).

\section{Quantitative microscopical characteristics}

Quantitative microscopical characteristics were mainly useful for identifying the different species of genus and also helpful in determination and authenticity of the plant. The results were shown in Table 1.

\begin{tabular}{cc} 
Table 1: Quantitative microscopy of $\boldsymbol{M}$. officinalis \\
\hline Leaf constant & Mean value \\
\hline Stomatal number & \\
Upper surface & $28.75 \pm 2.5$ \\
Lower surface & $38.37 \pm 2.5$ \\
Stomatal index & \\
Upper surface & $13.10 \pm 1.50$ \\
Lower surface & $12.58 \pm 1.10$ \\
Vein islet number & $96.25 \pm 4.79$ \\
Vein termination number & $27.50 \pm 2.87$ \\
Palisade ratio & $6.5 \pm 0.58$ \\
\hline
\end{tabular}

\section{DISCUSSION}

Morphological characters like colour, odour, taste etc are useful in gross identification. Microscopical characters are of important to distinguish authentic drug from an adulterant or a substitute. Powder study can be used in identification of authentic plant. As per WHO the macroscopic and microscopic description of medicinal plant is the initial step towards establishing its identity, it should be carried out before any tests are undertaken. ${ }^{13}$ The Pharmacognostical standards provide value added information about the plant.

\section{CONCLUSION}

The present study deals with the pharmacognostic evaluation of M. officinalis. The morphological and microscopical characters of plant

and powder were studied. The present study will provide useful information for correct identification, purity and standardization of plant. In addition the results of the present study could be useful for preparation of a monograph of the M. officinalis.

\section{ACKNOWLEDGEMENT}

The authors are grateful to Principal of Smt. C. V. Gajera Pharmacy Mahila College, Amreli (Gujarat), India for providing the facility to conduct the experimental work.

\section{CONFLICT OF INTEREST}

The authors have no conflict of interest to declare.

\section{ABBREVIATION USED}

mm: Millimeter; cm: Centimeter; m: Meter; E: Epidermis; UE: Upper epidermis; LE: Lower epidermis; P: Palisade cells; VS: Vascular strands; Sp: Spongy parenchyma; Cp: Cortical parenchyma; Cr: Cortical parenchyma; F: Fibers; Pi: Pith; C: Cork; Mr: Medullary ray; Xy: Xylem; Ph: Phloem.

\section{REFERENCES}

1. Anonymous. The wealth of India: A dictionary of Indian raw material and industrial products. Vol VI (L-M). New Delhi: Publisher and information Directorate (CSIR). 2003; 331

2. Marwat SK, Khan MA, Ahmad M, Zafar M, Ahmad F, Nazir A. Taxonomic studies of nodulated leguminous weeds from the flora of North Western part (Dera Ismail Khan) of Pakistan. Afr J Biotechno. 2009;8(10):2163-8.

3. Braga PC, Sasso MD, Lattuada N, et al. Antioxidant activity of Melilotus officinalis extract investigated by means of the radical scavenging activity, the chemiluminescence of human neutrophil bursts and lipoperoxidation assay. J Med Plants Res. 2013;7(7):358-65.

4. Ebrahimzadeh MA, Pourmorad F, Bekhradnia AR. Iron chelating activity, phenol and flavonoid content of some medicinal plants from Iran. Afr J Biotechnol. 2008;7(18):3188-92

5. Karakas FP, Yildirim A, Turker A. Biological screening of various medicinal plant extracts for antibacterial and antitumor activities, Turk J Biol. 2012;36(6):641-52.

6. Plesca-Manea L, Parvu AE, Parvu M, et al. Effects of Melilotus officinalis on acute inflammation. Phytother Res. 2002;16(4):316-9.

7. Kirtikar KR, Basu BD. Indian medicinal plants. $2^{\text {nd }}$ ed. Vol I. Dehradun: International Book Distributors. 2005; 704-705.

8. Nadkarni AK. Indian materia medica. $3^{\text {rd }}$ ed Vol I. Mumbai popular prakashan. 2007;786.

9. Anwer MS, Mohtasheem M, Azhar I, et al. Chemical constituents from Melilotus officinalis. J Basic App Sci. 2008;4(2):89-94.

10. Khandelwal KR. Practical Pharmacognosy: Techniques and Experiments $19^{\text {th }}$ ed. Pune: Nirali Prakashan. 2008;49-70.

11. Iyengar MA. Pharmacognosy of powdered crude drugs. $2^{\text {nd }}$ ed. Manipal 1980.

12. Jackson BP, Snowdon DW. Atlas of microscopy of medicinal plants, culinary herbs and spices. $1^{\text {st }}$ ed. New Delhi: CBS Publishers and Distributors (P) Ltd. 1992.

13. World Health Organisation. Quality control methods for medicinal plants. WHO library. Geneva, Switzerland. 2002:28-31.

\section{PICTORIAL ABSTRACT}

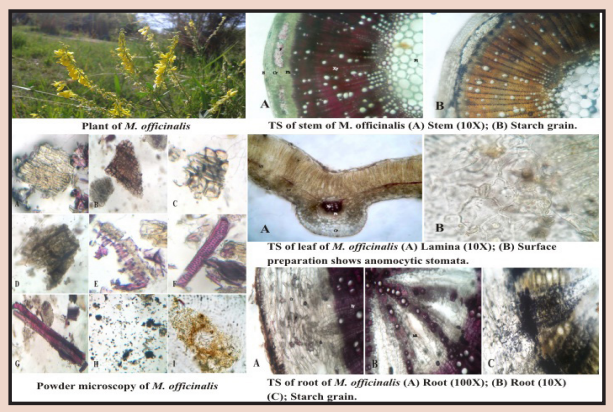

\section{SUMMARY}

- The present study deals with the estimation of morphological and microscopical characters of $M$. officinalis.

- The transverse section of leaf of $M$. officinalis shows lamina with single layered epidermis, anomocytic stomata, mesophyll, midrib with single layered epidermis and vascular strands were present in lamina.

- Stem contains single layered epidermis, cortex with several layers, phloem, xylem and starch grains.

- Root shows the presence of cork, phloem, xylem and starch grains

- The powder characteristics of $M$. officinalis revels the presence of epidermis, stomata, cork, parenchyma, mesophyll, fibers, spiral and pitted xylem vessels.

- Quantitative microscopic parameters of M. officinalis were also established. 


\section{ABOUT AUTHORS}

Mr. N. A. Sheikh: Working as Assistant Professor at Department of Pharmacology, Smt. C.V. Gajera Pharmacy Mahila College, Amreli and as PhD scholar at RK University, Rajkot. He is having 8 years of teaching experience in the field of Pharmacology. Mr. N. A. Sheikh has published 18 research papers in national and international peer reviewed journals. His area of research is Pharmacology, toxicology, Pharmacognosy and Phytochemistry.

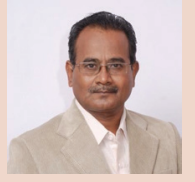

Dr.T. R. Desai: Obtained his PhD degree in pharmacology in 2005 from Saurashtra University, Rajkot. Currently he is positioned as Director, School of Pharmacy, RK University. Dr. Desai has 33 years of teaching experience. He has convened several conferences. He has 15 review and more than 60 research papers on his name. Dr. Desai had guided many postgraduate and PhD students. Four students were awarded PhD under his guidance and four were enrolled as PhD scholar. His area of research is clinical pharmacology and Toxicology.

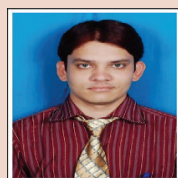

Mr. R. D. Patel: Working as Assistant Professor at Department of Pharmacognosy, Smt. C.V. Gajera Pharmacy Mahila College, Amreli. Mr. Patel is having 8 years of teaching experience in the field of Pharmacognosy. He is a $\mathrm{PhD}$ research scholar at NIMS University, Jaipur. He has published more than 30 research papers. Mr. Patel is a life time member of APTI and IPGA. His area of research is Pharmacognosy, Phytochemistry and Pharmacology. 